\title{
4. Some initial effects of pursuing and achieving native title recognition in the northern Kimberley
}

\section{Anthony Redmond}

This paper is an exploration of some shifts in regional socio-political dynamics brought about by native title litigation between Ngarinyin people and European pastoralist families in the northern Kimberley. Many of the visible signs of violence, mutual antagonism and clear conflicts of interest between the Indigenous and non-Indigenous groups who have co-existed on pastoral leases in the region have often been submerged in the course of everyday interactions between them which seek to highlight shared interests (Redmond 2005; Smith 2002, 2003). The inevitably adversarial process of pursuing native title, however, laid bare many of these conflicts of interest by presenting in the public forum of the Federal Court the moving personal testimonies of those who have lived through an era which arcs across the polarities of initial pastoral settlement (between the two World Wars) and the achievements of Ngarinyin native title holders in the courts (in 2004). Despite the painful revelations produced in court of the underlying power imbalances which have characterised their relationships, both parties are now required to, and indeed often espouse a desire to, continue to co-exist on this same country. Here I attempt to describe and analyse the shaken but persistently preservative nature of some of these relationships.

\section{Some initial effects of the judgement on local lives}

In August 2004, Justice Ross Sundberg of the Federal Court delivered to Ngarinyin people the final determination of their native title which recognised their exclusive possession of nearly 30000 square kilometres of their country in conjunction with the co-existent use and occupation of another 38000 square kilometres of non-Indigenous owned pastoral leases. The ceremony to present this determination was held at Anbada (Mt Barnett station, an Aboriginal owned pastoral lease), in Gubungarri clan country, 300 kilometres up the Gibb River Road from the service town of Derby. As one might expect, the event was something of a field-day for plying moral capital.

In attendance over three days were about 200 Ngarinyin people, Kimberley Land Council staff and consultants, various station owners and other interested parties, local politicians and a large contingent of lawyers including those acting for the applicants, those acting for the various respondents (e.g. the State, the Western Australian Pastoralists' and Graziers' Association (PGA), individual station 
owners, the Western Australian Fishing Industry Council, and others), the National Native Title Tribunal, and, of course, the whole Federal Court retinue.

In my view, by far the most frank appraisal of the recent relationship between the applicants and the respondents was given by the judge himself who declared that the legal battle had been a bitterly fought one in which 'no quarter' was given by either side. This statement was in stark contrast to the rather fulsome expressions of sentiments about peaceful co-existence and 'sharing country' emanating from some other parties including the local MP, officials from the Land Council and from the State. The PGA, which had maintained an extremely uncompromising stance throughout the proceedings, pushing the concept of adversarial litigation to its limits, later sent a letter to the National Native Title Tribunal complaining that they had not been invited to speak at the determination ceremony. Fred Chaney, the most senior member of the Tribunal in Western Australia, made a speech in which he frankly admitted his total failure in negotiating an outcome outside of the court. Chaney's admission of the failure of his strong overtures to the claimants to accept a negotiated outcome resonated strongly with the applicants and their legal counsel because the State's out-of-court offer, although only made after the whole of the case had been presented, apparently came nowhere near what the applicants hoped to, and as it turned out, did achieve in court. This result confirmed the applicants' suspicions that mediation may only succeed when the respondents are staring down the barrel of a certain and expensive failure in court, and perhaps not even then. ${ }^{l}$

Amongst the pastoralists attending the ceremony under the Kimberley Land Council's marquee was Susan Bradley, the manageress of two of the larger white-owned leases in the region. This socially prominent woman, once a local shire president and former owner of two iconic properties in the region (originally founded by the Duracks), accompanied by a female British colleague, took up her accustomed position at centre court. Mrs. Bradley is a member of what could be called, without exaggeration, the elite pastoralist contingent. In recent years she has hitched her wagon to the ever-rising fortunes of a Melbourne based QC, Alan Myers, who is now a major lease holder in this region. Although, as far as I am aware, she is not presently an owner of leases here in her own right, her status as something of a rural aristocrat has been preserved through this vicarious association and accompanied her rise to a prominent position on the Pastoral Lands Board. The owner himself seldom visited his remote properties and even his manageress resided part of the year in Broome, some 500 kilometres to the

\footnotetext{
${ }^{1}$ I do not have the space to go into this issue here, but the increasing (and understandable) reluctance of resource starved Representative Bodies to litigate native title claims might be seen as undermining applicants' capacity to achieve a reasonable outcome in negotiated settlements. Talking quietly, as Teddy Roosevelt famously observed, is most effective when 'carrying a big stick'.
} 
west. The day to day management of the station seemed to be designated to various underlings.

The presence of this particular manager at the determination ceremony was something of a provocation to some of the claimants. Over the course of the two years just prior to the instigation of the court proceedings, she and her husband had wooed the claimants with offers of joint economic enterprise initiatives. Although some senior Ngarinyin people always maintained serious reservations about such an involvement they were in no position to reject out of hand any potential economic development opportunities. Thus had begun an informal patronage relationship which saw a number of prominent business and legal people, including some top Sydney silks and company directors, visiting the outstation at Maranbabdidi and discussing their proposals for enterprise development, including purchasing cattle leases in the area in conjunction with Ngarinyin people. A charitable trust called the Wanjina Foundation was established partly for these purposes. However, the senior Ngarinyin people's misgivings about their benefactors began to increase when they were reportedly refused any positions on the board of that foundation. By now, these wealthy patrons had begun to be locally referred to as the 'million thousand mob'.

By the time the Ngarinyin were in the first stages of native title court hearings their alienation from the erstwhile philanthropists was complete. Some members of the 'million thousand mob' appeared to have tired of the joint-enterprise idea, and having accurately assessed the economic possibilities in the region through the auspices of the small office operated by Ngarinyin people in Derby, sought to buy privately the very stations for which the Ngarinyin had recently gained purchase approval from the board of the Indigenous Land Corporation (ILC). Not surprisingly, some members of the 'million thousand mob' were able to secure finances to make an offer which the ILC could come nowhere near matching. In a rather sad irony, the valuation of the stations was enhanced by the potential value of the Aboriginal rock art on those properties (Redmond 2002). The manageress for the Melbourne QC was one of these people and she was later to block station access to the small cultural tourism enterprise run by Ngarinyin people on adjacent Crown Land. During the subsequent court hearings on the station lands which she managed, she assisted the PGA's barristers in opposing the Ngarinyin claim. These barristers attempted to damage the credibility of a senior Aboriginal witness under-cross-examination by utilising Mrs. Bradley's rather jaundiced account of events which had occurred at a time when she had had privileged access to the claimants as a friend and mentor:

PGA BARRISTER: When you came to this place on the bush university, do you remember telling Susan Bradley and people there that you don't know anything about this site?

PADDY NEOWARRA: No. 
PGA B: You don't remember that?

PN: No.

PGA B: I put it to you didn't know those stories?

PN: No, I knew it. I knew it. They used to tell us about the story when I was just little boy about this country and the Wanjina, where it came from, yes.

PGA B: Yes. And you remembered that story right up 'til then, did you? PN: Yes, that's right, 'til today.

PGA B: Okay. And you didn't tell anyone - - -

PN: No.

PGA B: - - - in that bush university - just wait 'til I ask the question.

PN: Yes.

PGA B: You didn't tell anyone at that bush university time that you didn't know the story for here?

PN: No, I know the story but I didn't want to say 'til I get the permission from the people.

And then later again:

PGA B: you don't actually know where your country is any more do you?

$\mathrm{PN}$ : I know where it is.

PGA B: Do you?

PN: Yes.

PGA B: Well, do you remember a time in about 1996 or 1997 when you were on the bush university with Susan Bradley here?

PN: Yes. Well, I couldn't take the chopper right in; pretty rough.

PGA B: Well, you went - just a minute. Remember that? You went out looking for it and you told her you got lost and you didn't know where your country was. Remember that?

PN: I know I didn't say anything about that.

PGA B: You didn't say that?

PN: No.

PGA B: Well, I put it to you that you did say that at that time?

PN: No.

PGA B: So you didn't say to her that you didn't know where it was?

PN: I know where it is. ${ }^{2}$

These attempts to damage the reputation of the witness were, in the end, an abject failure, the judge summing up Neowarra's credibility as a witness in the most glowing terms.

${ }^{2}$ Neowarra $v$ Western Australia and Ors 2002, Federal Court Transcript (henceforth T), pp. 3305-06. 
Also in the elite pastoralist contingent at the ceremony was the owner-manager of a pastoral property adjacent to Anbada. This woman is the daughter of an eminent Sydney silk, and reportedly came into possession of the million-acre-plus property as a twenty-first birthday present from her father. Somewhat in contrast to her elite peers, she enjoys a reputation for roughing it and eschews the pearls and jodhpur look in favour of the more common white boss's uniform of Akubra, moleskins, and RM Williams boots.

Another group of pastoralists in the region is more of the 'battler' type, or at least perceive themselves this way. There are some very evident differences in the approaches to the cattle business between the 'battlers' and the more elite group. Most pertinently for the native title holders, the battler-type pastoralists have long supplemented their income by running home-stay and cultural tourism enterprises on their stations (often without the required licenses). Only at the far eastern end of the claim area, on El Questro Station, a multimillion dollar tourism operation in the Cockburn Ranges, have corporate pastoralists engaged in these lucrative activities in a sustained manner in addition to running cattle. Many of the elite pastoralists seemed to regard cultural tourism aimed at the general public as somewhat déclassé and invest a great deal of their self-image in the fact that they make their money from beef, something which has not been particularly difficult over the last decade when prices have remained relatively high and labour costs remain low. Nevertheless, as I have shown in another paper (Redmond 2002), at least two of the corporate-owned leases have been running exclusive tours to local rock art sites for small groups of wealthy visitors. These tours are presented as exclusive glimpses into the 'mysterious world of the Bradshaw paintings' and attract patronage from elite charitable foundations, such as one run by Dame Elizabeth Murdoch, which has funded rock-art research into the guyon guyon (or so-called Bradshaw Paintings) and wanjina sites by the controversial archaeologist, Graeme Walsh. In this respect the wealthy visitors are buying a form of cultural distinction, in Bourdieu's (1984) terms, rather than the wilderness or 'real live cattle ranch' experience offered on the battler stations. As Bourdieu pointed out, this cultural capital is readily convertible into actual capital.

My impression of the recent effects of having had native title recognised in the region is that there has been a considerable hardening of the position of the pastoralists, both of the elite and the battler variety. When I recently asked the senior Ngarinyin man, Paddy Neowarra, how the white pastoralists have reacted since the judgment came down, he replied (with his characteristic good grace):

I think they was a bit worried. That's what I can see. They was all worried. They think we are going to kick them off, or take over the whole country or this sort of thing. But we can't. If he's sitting on his own pastoral lease, well that's okay. Just not going over the line. You 
know, over his pastoral lease. Say you've got Crown Land over there, or reserve over there, he's not allowed to go over it because he's got to look after his own business, his own money what he can make, so we all, we help one another you know? We don't know what they want. [People are saying] that they are still locking all the gates.

During this visit in 2005, I received many reports of pastoralists locking gates to exclude local Aboriginal people. Though this was not uncommon before the judgment was delivered, there now seems to be a more systematic and coordinated attempt to exclude Ngarinyin people from some of these leases. It has been suggested that some of these pastoralists have received advice from the PGA that Aboriginal people are required to seek permission from them to enter their lease, something which is directly contrary to the terms of the judgement. Some lease-holders have informed the Representative Body for the area that all the native title holders need do is come up to the station-house and ask for the key, well aware that the majority of Aboriginal people in the area would be most disinclined to do so as a result the relative power imbalances which have prevailed for so long throughout the region and long set the tone of black and whitefella engagements. Some pastoralists have also claimed that they only lock the gates to keep out unauthorised tourists and to prevent disturbance of their stock. This campaign of locked gates suggests a renewed solidarity amongst the various pastoralists in the face of the newly recognised Aboriginal rights in the area. While, as Neowarra's statement indicates, none of the European leaseholder's material rights have been diminished by a native title judgement which grants primacy to their rights as pastoralists over native title rights, there appears to be a very real sense of a loss of political and moral supremacy on the part of the whitefella pastoralist class as a whole. This loss in itself may be a harbinger of cultural change in the area from which new power alignments may emerge over time.

\section{The Indigenous Land Corporation as a new pastoral boss}

The other major leaseholder in the region is the ILC, which purchased three large but nearly derelict properties 'on behalf of the traditional owners' in 1998 but which, in keeping with its current national policy, shows no inclination to divest these titles even to a well-organised Aboriginal corporate body with stringent business plans in place. Though not actually excluding their supposed beneficiaries from the properties, the ILC continues to conduct its business in such a way that the native title holders, all ex-cattle station workers, have at most a very peripheral role in decision making, despite the fact that they now legally hold exclusive possession of these stations 'as against the rest of the world'. Nevertheless, their most active involvement to date has been as CDEP-financed 'trainees' in menial station work. 
By way of contrast to the pastoralists' sense of drastic change in the wake of the judgement none of the Ngarinyin people I spoke to in 2005 could pinpoint any noticeable changes in their day to day lives 12 months on from determination, other than this increased resistance to their presence by many of the pastoralists. The native title holders have only recently established the Prescribed Body Corporate which is required to manage their rights in land. I expect that when this is in place more concrete economic and political gains may be achieved.

\section{The effects of the court process itself}

Perhaps one of the most intriguing aspects of the native title litigation process for me has been in observing how the claimants managed their relationships in court with the pastoralists on whose properties they reside and for whom they have worked, in many instances, for several generations. In this part of the paper, I discuss some of these engagements in the interests of showing how various Aboriginal people attempted to sustain the established tone of those relationships at the same time as frankly putting on record their own views of the power relationships involved. Many Ngarinyin people were all too aware that the court room drama presented a once in a lifetime opportunity to put their stories 'on the paper' (i.e. on the public record). As an ethnographer who has generally tip-toed around the deeply ambivalent and politically sensitive worker-boss relationships in the region for years (mainly for the self-serving purpose of retaining access to these settlements), I was sometimes startled by the frankness of the claimants' narratives (see also Merlan 1994, which challenged some earlier assumptions about the 'nostalgia' of Aboriginal workers for the pastoral era).

In one of the earliest court sessions at the Mowanjum community hall the local non-Indigenous pastoralists were present in force as their past and present workers prepared to take the stand. Indeed, one senior witness, now deceased, prefaced his evidence with a declaration of how his boss, sitting two rows behind him, 'been minding me very well'. The fact that he felt moved to offer this character reference for the same people who were opposing his rights and interests in land suggests that, on the one hand, he remained acutely aware of his own dependent situation, and secondly that this kind of contestation over land was not simply to be avoided. His character reference for his boss was made very much in the local Aboriginal rhetorical style in which denials of ill-intent and hostility frequently open up dispute proceedings.

Later, a former head stockman for the same pastoral lease (and who still resides there) took the stand. This man is also a renowned composer of traditional dreamt songs known as jurnba and carries his reputation as a barnman (healer/composer) with considerable gravitas through the local life-world. His evidence revealed that he had come to live at the station from a young age when his step-parents and extended family, who had been living a hunting and gathering life along 
the Drysdale River until the end of World War II, were captured by a police party, before which time, as the witness put it, they 'never work or anything like that, only just walking backward and forward'. ${ }^{3}$ When they returned to their 'special camp' on the Drysdale River the police arrived, put his parents and the other adults, male and female, on neck chains and took them to Mt Elizabeth. ${ }^{4}$ At Mt Elizabeth, his parents were tied to trees at night to prevent them running away. The young boy spent his time by himself down by the river. ${ }^{5}$ After about 10 days at Mt Elizabeth, his parents were taken in chains by the police from Mt Elizabeth west to Munja, leaving the boy behind at the station. His parents were being used by the police to find other people living in the bush. The police chained up the people living in the bush in order to, in the witness's words, 'make them civilised' ${ }^{6}$ Months later, at the beginning of the Wet, his step-parents returned to Mt Elizabeth and they were released from their chains. ${ }^{7}$ Meanwhile the witness had been cared for by another step-mother. His parents stopped there then and worked at the station for many years. The witness never attended school and began working as a boy at 'old Mt Elizabeth' 8 When he was 17, he began adult stock work: mustering, branding, droving cattle to Wyndham through Karunjie, and breaking horses. ${ }^{9}$ The witness lived and worked with a large group of older people ${ }^{10}$ in humpies about 100 yards from the boss's house. ${ }^{11}$ When the people living at Mt Elizabeth decided to set up their own community away from the station-house in 1982, the owner eventually agreed to give his work-force, in the witness's words again, 'a little bit of matchbox on a bit of side of road'. ${ }^{12}$ They lived in tents there for five years before the first permanent shelters were built. ${ }^{13}$

It was clear during the witness's evidence concerning the circumstances under which he came to live on Mt Elizabeth that a wave of annoyance was running through the pastoralist contingent. He was after all a 'favoured son', formerly head-stockman, and brought up from a child on the same beef, if maybe not the same cut, as the heir to the lease. After a short recess, the barrister for the PGA put it to the witness that the reason he and his family had been apprehended in their camp along the Drysdale River was that this was part of a benevolent campaign to control leprosy amongst the indigenous population. Here I cite the transcript of the cross-examination by the barrister for the PGA.

3 T2137 00-05.

4 T2137.15-45.

5 T2138. 00-46.

${ }^{6} \mathrm{~T} 2138.30-2139.40$.

7 T2138.35-2139.15, 2140.00-25.

8 T2146.35-2147.30, T2264.15-40.

9 T2148-2149.

10 T2214.25-45.

11 T2206.05-30.

12 T2250.00-10.

13 T2252.35-40. 
PGA Barrister: And I think you told the story about how they were your mother and your father, and I think it was just you - you didn't have any brother and sister - picked up by the Police; is that right?

WITNESS: Yes.

PGA B: And you were taken to Mount Elizabeth Station?

$\mathrm{W}$ : Yes.

PGA B: Has anyone ever told you that that was what used to be called a leprosy patrol?

W: Yes, just had a bit of sore on.

PGA B: Yes.

W: Just - just wanted to take them for bit of treatment.

PGA B: That's right. So your mum and dad, the Police collected them to take them for some treatment; is that right?

W: No.

PGA B: No?

W: No, they didn't have those sores. They just took them for - show those Police where the other people, what was living out in the bush.

PGA B: Yes.

W: That's all they took him for.

PGA B: So just so that I understand that. Has anyone ever told you that when the Police found people wandering in the bush, they would take them to be checked to see if they had leprosy?

W: Yes.

PGA B: And is that what you understood happened to your parents and to you?

W: Not that I know.

PGA B: Not that you know. Has anyone ever told you that when you got taken to Mount Elizabeth Station that you and your mum and dad were going to be taken off to the Leprosarium to be checked; did anyone ever tell you that?

W: No.

PGA B: No. Has anyone ever told you that [the lease-holder] who was the manager at the station, he asked the Police if you could stay there and you'd be checked out by the Flying Doctor when they came next time?

$\mathrm{W}$ : No.

PGA B: No one's ever told you that?

W: No.

PGA B: But you stayed at Mount Elizabeth Station, didn't you?

W: Yes. ${ }^{14}$

14 T2267.43-2269.45. 
The witness's revelations about his capture and subsequent life of work on the station was stated as a set of fairly unproblematised biographical facts and without any evident sense of malice towards the boss's family. Indeed, it is not at all uncommon for Ngarinyin people to express sympathy but also to laugh and joke about the humiliations and punishments inflicted on their older relatives, though whether this was a means of concealing their embarrassment at such subordination was never entirely clear to me. Othering one's own subordinate position is a common means of projection and denial. Though by no means naïve, simple, or compliant, the witness was also eager to 'do the right thing' by his employers and was probably dismayed at their annoyance. After all, in his terms he had just told his story as he had been asked to do.

Later in the proceedings, the witness was punished for his revelations when the barrister for the PGA asked him on the stand, in front of a roomful of his countrymen, whether or not it was true his current marriage was murlal or 'wrong way', a question which could have occurred to the barrister to ask only if he had been informed by those intimately acquainted with social life in the settlement. This use of shaming techniques continued throughout the proceedings through constant suggestions under cross-examination that individuals had either 'lost their culture', 'didn't know where their country was', were 'lying about their connections', 'didn't follow the law' or only danced or painted 'for money'. 15

I was surprised how robustly these individuals responded to such suggestions despite the formal and intimidating context of a courtroom, which for most of them had only ever been experienced as a place of punishment. That reservoirs of resilient self-appraisal underlay the usually very circumspect interpersonal styles of dealing with whitefellas came as even more of a shock I think to their employers and managers than it did to me. After all, a number of these pastoralists enjoyed a fairly jocular relationship with these same witnesses and made a show of this during the lunch breaks when they intermingled with the witnesses to show that they were, at heart, one of the boys.

\section{Conclusion}

In the aftermath of the judgement, the pastoralist contingent shows signs of having begun to splinter again, reverting to its constituent social classes, while maintaining solidarity in regards to the control of keys to locked gates. Some of the battler pastoralists have also begun to rekindle relationships with select groups of 'good blackfellas'.

The response of the European pastoralists suggests that they are undergoing a process of schismogenesis (Bateson 1935) both complementary (in regard to the

15 This last suggestion was a bit rich in a context in which not one of us whitefellas was earning less per day than a month's welfare payments for the witness being accused of venal intentions. 
claimants, and to their class counterparts) and symmetrical (in regard to each other). This movement parallels a similar trajectory which has long been emergent in the Ngarinyin community (Redmond 2006). For short periods of time, the two ethnic communities drew their various divergent interests together to partake in the adversarial litigation process. To sustain this unity of interests between their strongly autonomous fragments, two distinct notions of shared kinship, law and interests in land were pitted against each other, even to the extent that previous long-standing ideologies of some of the pastoralists being 'family' to Ngarinyin people (Redmond 2005) were put to a test — which they were seen to dismally fail by Ngarinyin people's standards.

Post-determination, indications exist that both of these cultural or ethnic blocs are now beginning to seek out new alliances as well as implementing further internal differentiations and distinctions which may well open up pathways out of the almost hegemonic relationships of the past. I expect that as a result of the litigation process, change in the political culture of the Gibb River Road pastoral region will be accelerated at the same time as resistance to such change sporadically intensifies over issues such as locked gates. The ILC cattle properties have the potential to significantly shape the direction of this change by bridging black and whitefella interests within an expanded beef (and possibly tourist) economy of scale. The native title stakeholders with rights in these S.47 type tracts of land, ${ }^{16}$ now the most robust form of land tenure in the Kimberley, need to take a place at the centre of that process to create any possibility for future economic and political developments.

\section{References}

Bateson, G. 1935. 'Culture contact and schismogenesis', Man (n.s.), 35: 178-83.

Bourdieu, P. 1984. Distinction: A Social Critique of the Judgement of Taste, Routledge, London.

Merlan, F. 1994. 'Narratives of survival in the post-colonial north,' Oceania, 65 (2): 155-74.

Neowarra vs. Western Australia and Ors 2002. Federal Court Transcript.

Redmond, A. 2002. “"Alien abductions", Kimberley Aboriginal cave paintings, and the speculation about human origins: on some investments in cultural tourism in the northern Kimberley, Western Australia', Australian Aboriginal Studies, 2002 (2):54-64.

\footnotetext{
16 Section 47 of the Act states that if a group of native title claimants held a pastoral lease at the time they lodged their claim, and are subsequently able to prove their native title claim, then all prior extinguishing acts are disregarded, yielding full beneficial ownership of the portion of the application area covered by the pastoral lease.
} 
Redmond, A. 2005. 'Strange relatives: mutualities and dependencies between Aborigines and pastoralists in the Northern Kimberley', Oceania (Special Issue), 75 (3): 234-46.

Redmond, A. 2006. 'Further on up the road: community trucks and the moving settlement', in G. Cowlishaw, T. Lea and E. Kowal (eds), Moving on: Critical Indigenous Studies, Charles Darwin University Press, Darwin.

Smith, B. R. 2002. 'Pastoralism, land and Aboriginal existence in central Cape York Peninsula', Anthropology in Action, 9: 21-30.

Smith, B. R. 2003. 'Whither "certainty"? Coexistence, change and land rights in northern Queensland', Anthropological Forum, 13: 27-8. 